\title{
Intramural esophageal tumors
}

\author{
Mariusz P. Łochowski, Katarzyna Kozak, Marek Rębowski, Józef Kozak
}

Clinic of Thoracic Surgery and Respiratory Rehabilitation, Medical University of Lodz, M. Copernicus Provincial

Specialist Hospital, Lodz, Poland

Kardiochirurgia i Torakochirurgia Polska 2016; 13 (4): 319-321

\begin{abstract}
Introduction: Intramural esophageal tumors (IET) are located between unchanged mucous membrane and muscularis mucosae. They can be both benign and malignant.

Aim: To evaluate diagnostic and therapeutic difficulties of IET. Material and methods: During the years 2010-2015, 11 patients with IET were treated in our clinic. Diagnostics included gastroscopy, computed tomography of the chest, endoscopic ultrasound (EUS) guided fine needle biopsy, and positron emission tomography (PET) of the esophagus in cases with no histopathological confirmation.

Results: Based on the conducted analysis we diagnosed 1 case of gastrointestinal stromal tumor (GIST), 1 case of adenocarcinoma, and 2 cases of esophageal cysts. In another 7 cases radiological images resembled leiomyoma but with no histopathological confirmation. Esophagectomy was performed in 2 cases of malignant tumors and 1 case of a large benign tumor. In other cases surgical enucleation of tumors was performed. Postoperatively we diagnosed 6 cases of leiomyoma, 1 case of schwannoma, 2 esophageal cysts, 1 case of GIST and 1 of esophageal cancer.

Conclusions: Intramural esophageal tumors is a very diverse group of tumors, both malignant and benign. In every case of IET we should seek histopathological conformation. Treatment of IET depends on localization, size and histopathological type of lesion.
\end{abstract}

Key words: intramural esophageal tumors, diagnostics, treatment.

\section{Introduction}

Intramural esophageal tumors (IET) is group of pathological lesions arising from vessels, nerves, smooth muscles, and mucous glands located beneath unchanged mucous membrane of the esophagus. These lesions may develop into both benign and malignant tumors or developmental disorders such as cysts. The most frequent malignant tumors are gastrointestinal stromal tumor (GIST)

\section{Streszczenie}

Wstęp: Śródścienne guzy przełyku (ŚGP) zlokalizowane są pomiędzy niezmienioną błoną śluzową a mięśniówką. Patologie te mogą mieć charakter łagodny lub złośliwy.

Cel: Przedstawienie problemów diagnostyczno-leczniczych ŚGP. Materiat i metody: W latach 2010-2015 leczono 11 chorych z ŚGP. Diagnostykę przeprowadzono na podstawie następujących badań: gastroskopii, tomografii komputerowej (TK) klatki piersiowej, ultrasonografii przezprzełykowej z biopsją cienkoigłową (EUS z FNB) i pozytonowej tomografii emisyjnej (PET) przełyku w przypadku braku weryfikacji histopatologicznej.

Wyniki: Dzięki przeprowadzonej diagnostyce rozpoznano: nowotwór podścieliskowy przewodu pokarmowego (GIST) w 1 przypadku, raka gruczołowego przełyku w 1 przypadku oraz 2 torbiele przełyku. W pozostałych 7 przypadkach nie uzyskano rozpoznania histopatologicznego. Na podstawie obrazu radiologicznego wysunięto podejrzenie mięśniaka gładkokomórkowego. Resekcję przełyku wykonano w guzach złośliwych oraz w 1 przypadku dużej zmiany łagodnej. W pozostałych przypadkach, gdzie podejrzewano guz łagodny, przeprowadzono chirurgiczne wyłuszczenie guza. Pooperacyjnie rozpoznano: mięśniaka gładkokomórkowego w 6 przypadkach, schwannoma w 1 przypadku, 2 torbiele przełyku i po 1 przypadku GIST i raka przełyku.

Wnioski: Śródścienne guzy przełyku stanowią zróżnicowaną grupę nowotworów łagodnych i złośliwych. W każdym przypadku ŚGP należy dążyć do jego histopatologicznego rozpoznania. Leczenie zależy od lokalizacji, wielkości i typu histopatologicznego zmiany.

Słowa kluczowe: śródścienne guzy przełyku, diagnostyka, leczenie.

and esophageal cancer. Benign esophageal tumors are rare and account for less than $1 \%$ of esophageal tumors [1, 2]. The classification of benign intramural esophageal tumors includes leiomyomas, schwannomas, and lipomas.

\section{Aim}

The aim of the study is to present 5 years of experience of diagnostics and treatment of IET. 

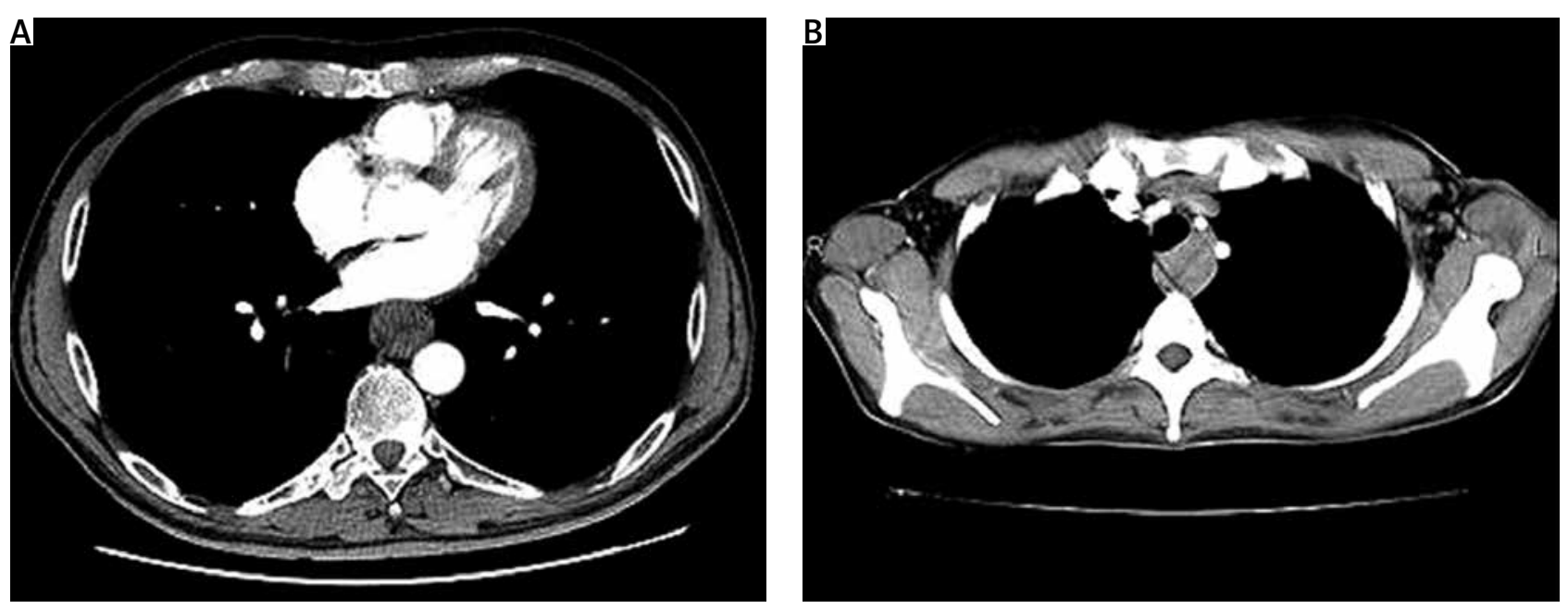

Fig. 1. A - Gastrointestinal stromal tumor of the esophagus, B - schwannoma of the esophagus

\section{Material and methods}

In the years 2011-2015 eleven patients with IET were treated in our clinic: 6 males and 5 females, aged between 28 and 65 years (mean age: 52). The main symptom reported by all patients was dysphagia progressing for several months. Every patient was diagnosed by means of computed tomography of the chest and gastroscopy. Computed tomography (CT) scan revealed various sized tumors $(3-10 \mathrm{~cm})$ located in the esophagus. In 1 case the lesion was located in the upper esophagus, in 3 cases the middle esophagus and in the other 7 cases the lower esophagus (Fig. 1). Gastroscopy revealed unchanged mucous tissue elevated by an intramural lesion. In all cases an endoscopic ultrasound (EUS) guided fine needle biopsy was performed. One patient was diagnosed with GIST and 1 with esophageal cancer, whereas in the other cases biopsy results were nondiagnostic. In those cases positron emission tomography (PET) was conducted, but the results also did not establish a final diagnosis (Tab. I).

\section{Results}

The patient with GIST was treated with partial resection of the esophagus using the Lewis-Tanner technique. The patient with esophageal cancer was treated with transhiatal excision of the esophagus using the Orringer technique. In the other cases with benign lesions surgical enucleation was conducted except for 1 patient with leiomyoma. In this case esophageal resection by Lewis-Tanner technique was performed. One case of esophageal cyst was treated with radical excision. Postoperatively there were no complications. Diagnosis was established on immunohistochemical examination of the excised lesion (Tab. II). When the diagnosis of malignant tumor was established, the patient was treated with adjuvant chemotherapy.

\section{Discussion}

Introduction of new techniques of chest imaging enabled more frequent diagnosis of intramural lesions of the esophagus. Immunohistochemical examination allowed these lesions to be differentiated. Two percent of all esophageal tumors are leiomyomas. They are the most common benign tumors. They are localized mostly intramurally and can reach considerable sizes [2-4]. Over a half of all patients in this study were diagnosed with leiomyoma.

Tab. I. Intramural esophageal tumors - location, size, diagnosis and treatment

\begin{tabular}{|c|c|c|c|c|c|c|c|}
\hline \multirow[t]{2}{*}{ Type of tumor } & \multirow[t]{2}{*}{$N$} & \multicolumn{3}{|c|}{ Location in esophagus } & \multirow{2}{*}{$\begin{array}{l}\text { Size } \\
{[\mathrm{cm}]}\end{array}$} & \multirow[t]{2}{*}{ Diagnosis } & \multirow[t]{2}{*}{ Treatment } \\
\hline & & Upper & Middle & Lower & & & \\
\hline Leiomyoma & 6 & - & 1 & 5 & $5-10$ & RTG, CT, EUS-FNA, PET & $\begin{array}{c}\text { Surgical enucleation } \\
5 \\
\text { Lewis-Tanner operation } \\
1\end{array}$ \\
\hline
\end{tabular}

\begin{tabular}{|c|c|c|c|c|c|c|c|}
\hline Schwannoma & 1 & 1 & - & - & 3 & RTG, CT, EUS-FNA & $\begin{array}{c}\text { Surgical enucleation } \\
1\end{array}$ \\
\hline GIST & 1 & - & 1 & - & 4 & RTG, CT, EUS-FNA & $\begin{array}{c}\text { Lewis-Tanner operation } \\
1\end{array}$ \\
\hline Cysts & 2 & - & 1 & 1 & $5-10$ & RTG, CT, EUS-FNA & $\begin{array}{l}\text { Surgical excision } \\
2\end{array}$ \\
\hline Carcinoma & 1 & - & - & 1 & 8 & RTG, CT, EUS-FNA, PET & $\begin{array}{l}\text { Orringer operation } \\
1\end{array}$ \\
\hline Total & 11 & 1 & 3 & 7 & & & \\
\hline
\end{tabular}


Tab. II. Immunohistochemical differentiation of the intramural esophageal tumors

\begin{tabular}{lccccc} 
Type of tumor & CD 117 & CD34 & SMA & Desmin & S-100 \\
Leiomyoma & - & $+(10-15 \%)$ & + & + & + Rare \\
\hline Schwannoma & - & + & - & + & + \\
\hline Fibromatosis & +- & + Rare & + & + Rare & - \\
\hline GIST & + & $+(60-70 \%)$ & $+(30-40 \%)$ & Very rare & $+(5 \%)$ \\
\hline
\end{tabular}

Schwannoma and GIST have rarely been diagnosed so far due to great similarity to leiomyoma both in clinical course and imaging $[2,5]$. Esophageal cysts look distinctly different in EUS and CT scans than solid tumors; therefore they are easier to diagnose [6-8]. Esophageal cysts are often located circularly in the esophagus. It is believed they originate from epithelial cells forming mucous glands located intramurally $[1,9]$.

The clinical course of patients with IET is distinctive. Major complaints are progressive dysphagia, hemoptysis, dyspnea, and chest pain $[2,6,10,11]$. In our experience patients were mainly complaining of dysphagia.

Esophageal cysts occur mainly in adults, less frequently in younger patients $[6,8]$. Leiomyomas and schwannomas are more common in middle aged patients. Malignant lesions are characteristic for people beyond the age of 50 [5, 9]. Gender has not been associated with frequency of such lesions $[4,5,9,11]$.

The patient is initially diagnosed by means of chest $X$-ray and gastroscopy. Radiograms frequently detect lumps located in the posterior mediastinum around the esophagus. Gastroscopy often shows elevation of unchanged esophageal mucosa to esophagus lumen $[3,7]$. Computed tomography allows one not only to precisely localize the tumor but also to determine its structure and size [2, 3, 10]. Magnetic resonance imaging allows one to differentiate paraesophageal from paravertebral localization of the tumor [7]. The majority of IET are located in the lower third of the esophagus [3-5]. Positron emission tomography is helpful to verify the status of lymph nodes and possible metastases [12]. In our study PET examination did not prove useful in differential diagnosis of IET. In our experience EUS provides the most insight into tumor structure and enables one to perform direct biopsy. In cases of suspected cysts, antibiotic prophylaxis is recommended, because of reported mediastinitis after biopsy of the cyst $[6,7]$. In our study EUS biopsy led to the diagnosis in 4/11 (36\%) Patients.

The method of treatment depends on the size, type of tumor, its location and general condition of the patient [1, 3 , 4]. Malignant lesions are treated with esophageal resection. Benign lesions can be removed by performing enucleation in VATS or thoracotomy $[1,3,4,10,13]$. Inability to enucleate or major damage to the esophageal mucosa is an indication for resection of the esophagus. Some authors believe that the biopsy of the tumor performed during EUS may hinder its later separation from the esophageal mucosa $[1,3,13]$. While some recommend observation of benign tumors up to $5 \mathrm{~cm}$ in diameter $[1,3]$, the major- ity of authors recommend surgical removal of all lesions (including cysts) due to the possibility of their malignant transformation $[1,4,13]$.

Intramural esophageal tumors are described on the basis of case reports; therefore generally their natural history is unknown.

\section{Conclusions}

Intramural esophageal tumors are a diverse group of neoplasms, both benign and malignant. In any case of IET we should seek a histopathological diagnosis. Treatment of IET depends on the location, size and histopathological type.

\section{Disclosure}

Authors report no conflict of interest.

\section{References}

1. Punpale A, Rangole A, Bhambhani N, Karimndackal G, Desai N, de Souza A, Pramesh CS, Jambhekar N, Mistry MC. Leiomyoma of esophagus. Ann Thorac Cardiovasc Surg 2007; 13: 78-81.

2. Kitada M, Matsuda Y, Hayash S, Ishibashi K, Oikawa K, Miyokawa N. Esophageal schwannoma: a case report. World J Surg Oncol 2013; 11: 253-255.

3. Sun X, Wang J, Yang G. Surgical treatment of esophageal leiomyoma larger than $5 \mathrm{~cm}$ in diameter: a case report and review of the literature. J Thorac Dis 2012; 4: 323-326.

4. De Giacomo T, Bruschini P, Arcieri S, Ruberto F, Venuta F, Diso D, Francioni F. Partial oesophagectomy for giant leiomyoma of the oesophagus: report o 7 cases. Eur J Cardiothorac Surg 2015; 47: 143-145.

5. Markakis CG, Spartalis ED, Liarmakopoulos E, Kavoura EG, Tomas P. Esophageal gastrointestinal stromal tumor: diagnostic complexity and management pitfall. Case Rep Surg 2013; 2013: 968394.

6. Chaudhary V, Rana SS, Sharma V, Sharma AR, Nada R, Gupta R, Dutta U, Singh K, Bhasin DK. Esophageal duplication cyst in an adult masquerading as submucosal tumor. Endosc Ultrasound 2013; 2: 165-167.

7. Novallis P, Graffeo M, Sparano L, Sanchez AM, Lovera M, Tonti C, Paterlini A, Morandi G. Endoultrasonography (EUS) examination of the esophagus in the diagnosis of esophageal duplication: a case report and a review of the literature. Eur Rev Med Pharmacol Sci 2015; 19: 3041-3045.

8. Vougiouklakis T, Mitselou A, Dallas P, Peschos D, Stefanou D, lochin E, Charalabopoulos K, Agnantis NJ. Inclusion cyst of esophagus: case report and review of the literature. Exp Oncol 2003; 25: 22-24.

9. Schmitz KJ, König C, Riesener KP. Intramural carcinoma of the oesophagogastric junction. BMJ Case Rep 2012; 2012. pii: bcr0320126080.

10. Kozak K, Kowalczyk M, Jesionek-Kupnicka D, Kozak J. Benign intramural schwannoma of the esophagus case report. Kardiol Torakochir Pol 2015; 12: 69-71.

11. Choo SS, Smith M, Cimini-Mathews A, Yang SC. An early presenting esophageal schwannoma. Gastroenterol Res Pract 2011; 2011: 165120.

12. Christopher PR, Kingsley PA, Bedi HS, Kwatra KS, Rathore S, Das KC. Large Mid-esophageal granular cell tumor: benign versus malignant. Rare Tumors 2015; 7: 5772.

13. Neoral C, Aujeský R, Skarda J, Vrba R, Chudáček J, Bohanes T, Vomáčková K. Thoracoscopic treatment of benign esophageal tumors. Wideochir Inne Tech Maloinwazyjne 2012; 7: 294-298. 